\title{
Mechanochemical Treatment to Remove Arsenic from Copper Ore
}

\author{
Shingo Ishihara *, Kozo Shinoda and Junya Kano \\ Institute of Multidisciplinary Research for Advanced Materials, Tohoku University, Sendai 984-8577, Japan; \\ kozo.shinoda.e8@tohoku.ac.jp (K.S.); kano@tohoku.ac.jp (J.K.) \\ * Correspondence: ishihara@tohoku.ac.jp; Tel.: +81-22-217-5136
}

Received: 22 April 2019; Accepted: 4 June 2019; Published: 6 June 2019

\begin{abstract}
This study tested the removal of arsenic from copper ore concentrate via a mechanochemical treatment by planetary ball milling. The harmful components of ore, such as arsenic, are increasing year by year and decreasing the copper grade, therefore there is a strong need to improve the separation of arsenic from copper ore. The effect of grinding as a result of chemical activation caused by mechanochemical treatment was evaluated by XRD and X-ray absorption spectroscopy (XAS) measurements. From the results of the XRD analysis, several crystalline minerals were identified from the original samples. The diffraction peaks of the original samples were reduced by grinding, although grinding did not generate any new diffraction peaks. The comparison of the results of grinding in dry and wet conditions showed that the rate of disappearance of the crystalline minerals was faster in dry grinding than in wet grinding. To clarify the chemical state of arsenic in copper ore, XAS analysis was carried out. The results indicated that the arsenic compound changed from sulfide, in the original sample, to oxide after grinding. As a result of oxidation, the arsenic was easy to dissolve in a water and alkaline solution, and optimized dry and wet grinding conditions achieved up to $76 \%$ arsenic removal efficiency.
\end{abstract}

Keywords: mechanochemical; copper; arsenic; ore; ball milling

\section{Introduction}

Copper smelting is an important technology used to develop industrial and social infrastructure. In general, copper ore is ground as a preliminary treatment to separate and concentrate the copper components. Copper grade and the copper recovery rate are prioritized in current mining operations, so grinding has rarely been performed with consideration of the handling of harmful components in ore. The harmful components of ore such as arsenic (As) are increasing year by year, decreasing the copper grade. As exposure is a significant problem for the surrounding environment and the health of the miners [1-4].

As removal treatment in the copper smelting process has been widely studied by many researchers in the past decades. Both pyrometallurgical and hydrometallurgical methods are used in As removal processes [5-8]. At present, most studies focus on the hydrometallurgical treatment of the ore or waste of smelting processes, mainly using water, acid, and alkaline leaching methods [9]. The different leaching rates of arsenic in water and diluted sulfuric acid from copper smelter wastes were compared by Kashiwakura et al. [10]. Their study indicated that sulfuric acid could achieve a high leaching efficiency. Liu et al. studied the leaching process of arsenic in a sulfide system and showed that the high arsenic leaching rate might be obtained by high consumption of sulfide and alkali [11-14].

On the other hand, the mechanochemical method recently attracted significant attention as an alternative method to treat various chemical reactions [15-17]. It showed the ability to increase the leaching rate of non-ferrous metals from sulfide ores [18]. A high-intensity grinding operation causes a 
decrease in the particle size and the fractures create the new surface. As a result, physical and chemical reactions are induced in the materials. At present, grinding has only been performed to control particle size, as a preliminary treatment, in the copper smelting process; however, if the mechanochemical method can cause reactions that promote the separation of arsenic from ore, the copper smelting process can be dramatically improved.

This study was carried out to investigate arsenic removal from copper ore concentrate by mechanical treatment using a planetary ball mill. Considering the cost of the actual mining operation, this study focused on water leaching. The influence of dry and wet grinding on the rate of water leaching was confirmed by inductively coupled plasma (ICP) measurement. The effects of grinding the ore were observed by X-ray diffraction (XRD) and X-ray absorption spectroscopy (XAS) measurements. The optimal grinding conditions of mechanochemical treatment for the removal of arsenic from copper ore were discussed.

\section{Materials and Methods}

\subsection{Materials and Experimental Conditions}

In this study, copper ore concentrate from the Japan Oil, Gas and Metals National Corporation (JOGMEC) (Tokyo, Japan) was used. The chemical compositions of the ore are shown in Table 1, which were the results of Inductively Coupled Plasma-Mass Spectrometry (ICP-MS) analysis. A planetary ball mill (pulverisette-7, Fritsch Japan, Tokyo, Japan) with Zirconia pot and balls, was used for grinding. The mass of the balls was set to $75 \mathrm{~g}$, and the diameter of balls was $15 \mathrm{~mm}$. The rotational speed was $600 \mathrm{rpm}$. The volume of the pot was $45 \mathrm{~mL}$. Grinding was performed in an air atmosphere. The sample weight was $4 \mathrm{~g}$. In the wet grinding, $20 \mathrm{~mL}$ distilled water were introduced into the pot. In the elution test, $2.0 \mathrm{~g}$ solid samples were charged in a beaker with $200 \mathrm{~mL}$ distilled water and stirred by a magnetic stirrer. Next, $5 \mathrm{~mL}$ of the solution was collected at each sampling time, the filtrate after filtration was diluted in a measuring cylinder to $10 \mathrm{~mL}$ total. The wet grinding sample was filtered through filter paper and elution test was performed without drying. The filtered liquid was analyzed by ICP-MS (ICPM-8500, Shimadzu, Kyoto, Japan). The elution rate was defined as the ratio of the mass concentration of each element dissolved in the elution test to the mass concentration in the original sample.

Table 1. Chemical composition of copper ore used in this study, analyzed by Inductively Coupled Plasma-Mass Spectrometry (ICP-MS).

\begin{tabular}{cc}
\hline Element & wt \% \\
\hline $\mathrm{Cu}$ & 30.77 \\
$\mathrm{As}$ & 5.76 \\
$\mathrm{Fe}$ & 12.90 \\
$\mathrm{~S}$ & 28.80 \\
$\mathrm{Zn}$ & 2.06 \\
$\mathrm{~Pb}$ & 0.24 \\
\hline
\end{tabular}

\subsection{Analysis Methods}

XRD analysis was performed using an X-ray diffractometer (RINT2200, Rigaku, Tokyo, Japan). XAS measurements were carried out using the in-house X-ray absorption spectrometer (R-XAS Looper, Rigaku, Tokyo, Japan) developed by Taguchi et al. [19]. The measurement sample powder was diluted with boron nitride $(\mathrm{BN})$, molded into a $10 \mathrm{~mm}$ diameter tablet, and measured by the transmission method around the energies of the As-K X-ray absorption edge $(11,866 \mathrm{eV})$. White $\mathrm{X}$-rays were generated from a demountable $X$-ray tube using a molybdenum (Mo) target and lanthanum hexaboride $\left(\mathrm{LaB}_{6}\right)$ filament, which were monochromized by the bent Johansson-type single crystal Si (620) in X-ray absorption near edge structure (XANES) and extended X-ray absorption fine structure (EXAFS) measurements. The processing of the data and determination of the structural parameters were done 
using the Rigaku's XAFS analysis program package (REX2000), with the FEFF 8.20 code [20,21] for calculating backscattering amplitude and phase shift.

\section{Results}

\subsection{Mechanochemical Effect}

Figure 1 shows the results of the elution test for $\mathrm{As}$, copper $(\mathrm{Cu})$, and ferrum $(\mathrm{Fe})$ from the original (as-prepared) samples. In the original samples, As, $\mathrm{Cu}$ and Fe hardly dissolved, even when the elution time was increased.

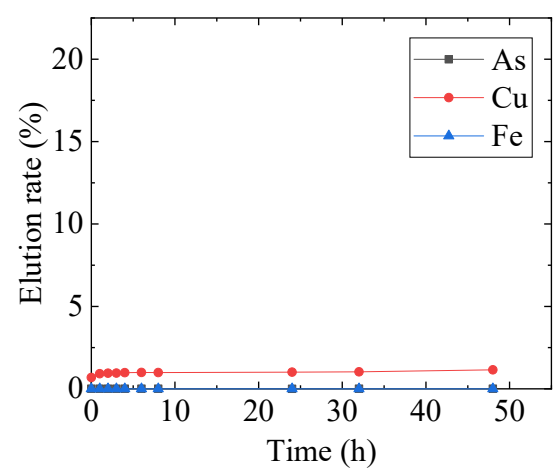

Figure 1. Elution rate of $\mathrm{As}, \mathrm{Cu}$ and $\mathrm{Fe}$ from original (as-prepared) samples in water.

To confirm the effect of grinding on the elution rate of the materials, dry and wet grinding was performed and the grinding time was changed from $1 \mathrm{~h}$ to $8 \mathrm{~h}$. Figure 2 shows the results of the elution test as an effect of dry grinding. In dry grinding, As and Fe were dissolved at an early stage of the elution test, when the grinding time was above $4 \mathrm{~h}$, and the elution rate of As showed a maximum value of $18 \%$ at the grinding time of $4 \mathrm{~h}$. Fe showed almost the same elution behavior as As. On the other hand, $\mathrm{Cu}$ showed different elution behavior. The highest elution rate was obtained when the grinding time was $1 \mathrm{~h}$, and the elution rate decreased as the grinding time increased. The elution rate increased monotonically with increasing elution time in the elution test. Figure 3 shows the results of the elution test as an effect of wet grinding. In wet grinding, As and Fe did not dissolve, regardless of the elution time. However, $\mathrm{Cu}$ dissolved with all grinding times and the elution rate of $\mathrm{Cu}$ was largest after $2 \mathrm{~h}$ of wet grinding. The elution rate of $\mathrm{Cu}$ increased monotonically with increasing elution time. Here, in order to confirm whether there was a dissolved component in the water added in wet grinding, the sample after grinding was filtered and ICP analysis of the filtrate was performed. As a result, As, $\mathrm{Cu}$, and Fe were hardly detected in the filtrate. It was found that the state of the compound of the sample was changed by wet grinding but was only eluted in the subsequent elution test. To investigate the effects of grinding, a comparison in the crystalline phase using XRD analysis was carried out for original and ground samples after grinding for $1 \mathrm{~h}$ to $12 \mathrm{~h}$. Figure 4 shows the resultant XRD profiles. In the original sample, crystalline minerals including $\mathrm{As}$, tennantite $(\mathrm{Cu}, \mathrm{Fe}){ }_{12} \mathrm{As}_{4} \mathrm{~S}_{13}$, and minerals such as chalcopyrite $\mathrm{CuFeS}_{2}$, enargite $\mathrm{Cu}_{3} \mathrm{AsS}_{4}$, pyrite $\mathrm{FeS}_{2}$, and quartz $\mathrm{SiO}_{2}$, were identified. Although the crystallinity of these minerals was reduced via the grinding treatment, there were no new crystalline mineral phases observed. The reduction of crystallinity of arsenic containing minerals such as tennantite and enagite was particularly significant, while the reduction of crystallinity of pyrite was moderate. A comparison of the dry and wet grinding condition indicated that the crystallinity reducing rate was higher in the dry ground sample than in the wet. Figure 5 shows the effect of grinding time on particle size distribution, measured with a particle size analyzer (Microtrac MT3000, MicrotracBEL, Osaka, Japan). Figure 5 shows that particle size decreased rapidly in wet grinding rather than dry grinding. In addition, the grinding limit of wet grinding was smaller than that of dry grinding. The results indicated that grinding energy acted on the amorphization of the crystal structure rather than on the reduction of the particle size in dry grinding. In contrast, grinding energy acted on the reduction of the particle size rather than the amorphization of the crystal structure in wet grinding. 


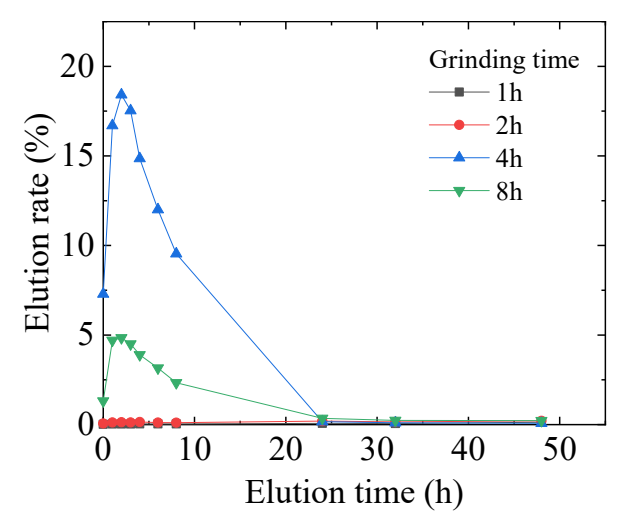

(a)

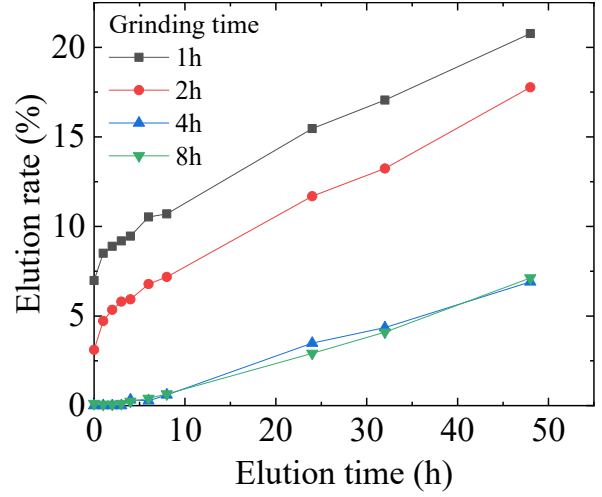

(b)

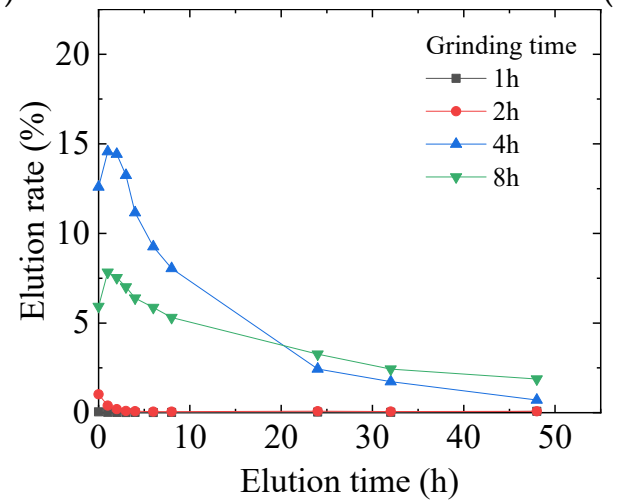

(c)

Figure 2. Elution rate of (a) As, (b) $\mathrm{Cu}$ and (c) Fe from dry ground samples at different grinding times.

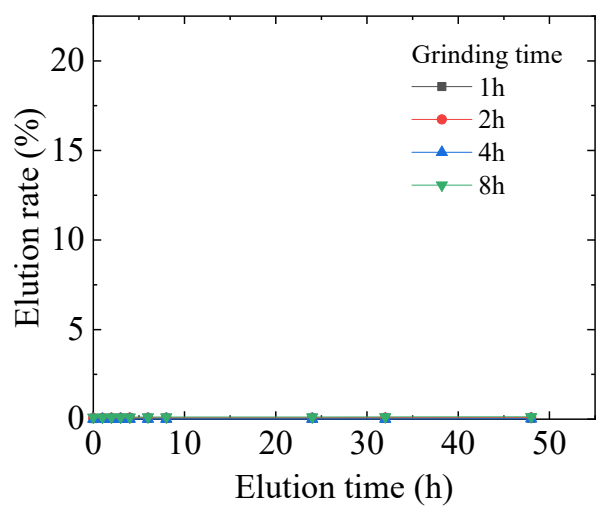

(a)

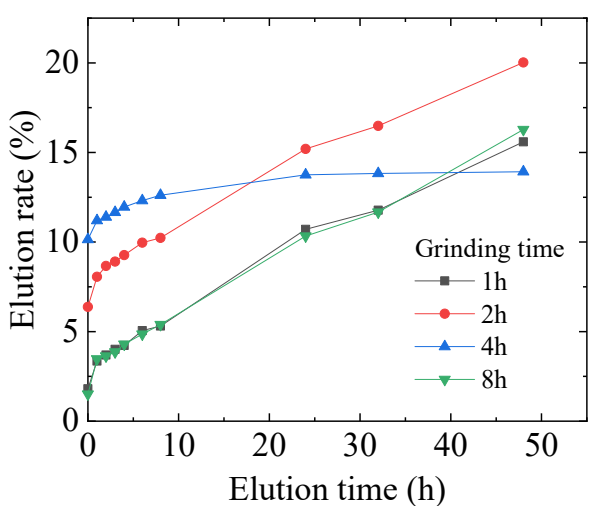

(b)

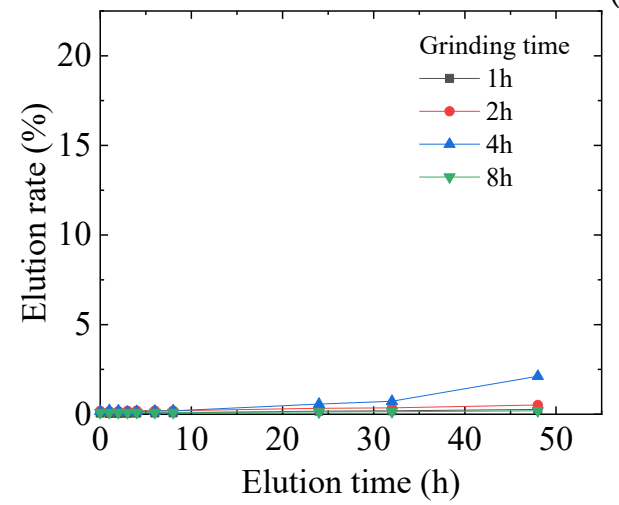

(c)

Figure 3. Elution rate of (a) As, (b) Cu and (c) Fe from wet ground samples at different grinding times. 


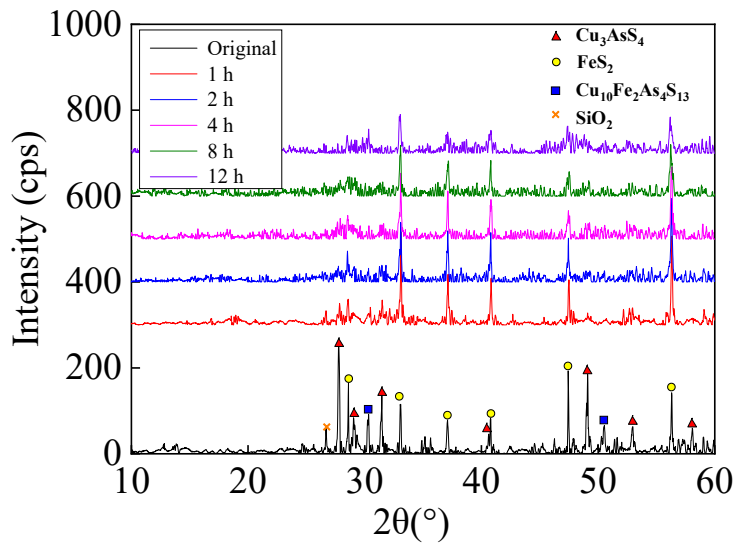

(a)

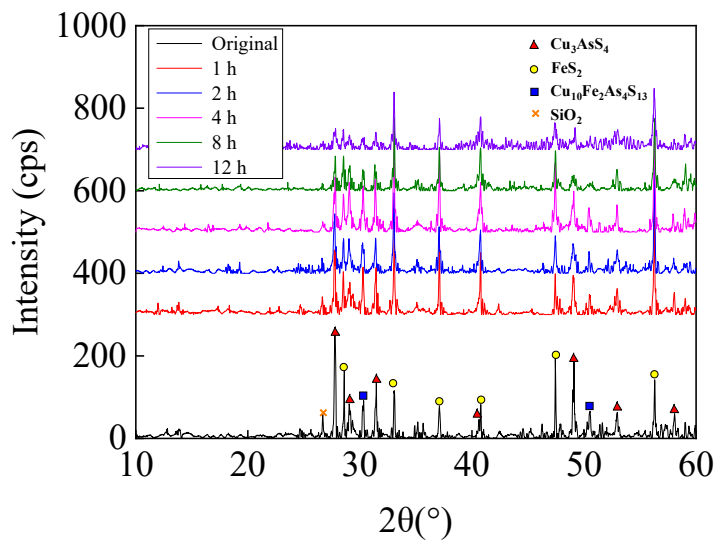

(b)

Figure 4. XRD analysis of dry and wet grinding as an effect of grinding time; (a) dry grinding; (b) wet grinding.

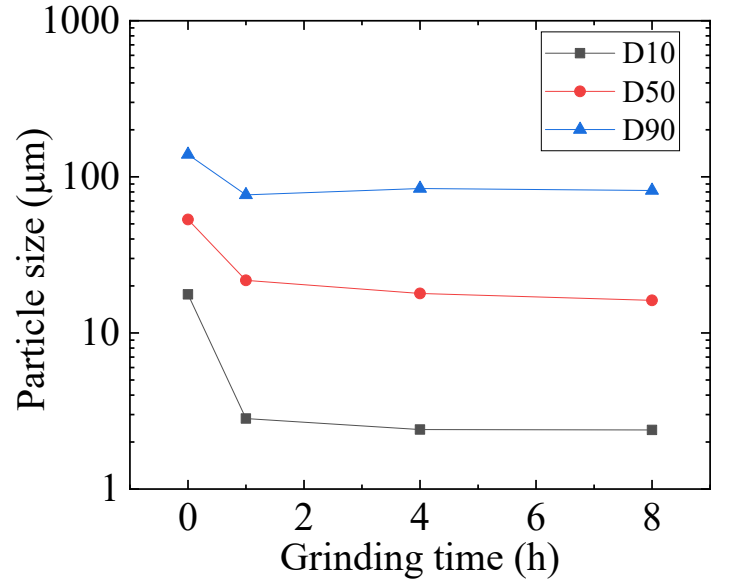

(a)

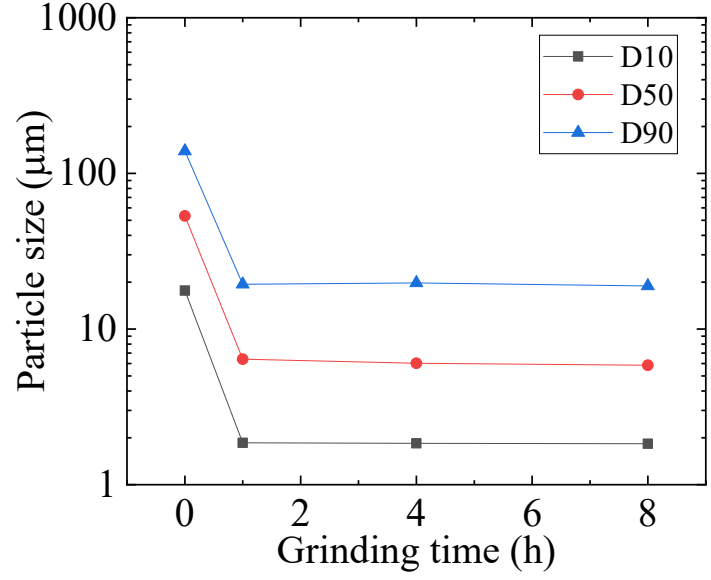

(b)

Figure 5. The effect of grinding time on the d10, d50 and d90 diameter of dry and wet ground samples; (a) dry grinding; (b) wet grinding.

In order to clarify the chemical state of As, the samples were analyzed before and after grinding by X-ray absorption spectroscopy (XAS). The radial structure function (RSF) profiles calculated by Fourier transformation, from the $k^{3}$ weighted EXAFS spectra of original and dry ground samples before and after leaching, are shown in Figure 6, along with several reference curves for enargite, arsenic(III) trioxide $\mathrm{As}_{2} \mathrm{O}_{3}$, and arsenic $(\mathrm{V})$ pentoxide $\mathrm{As}_{2} \mathrm{O}_{5}$ standards. This figure indicates that the profile of EXAFS spectra and RSFs of the original samples is similar to enargite, meaning that As is present as sulfide. It was found that the chemical state of As hardly changed, even for the elution test of the original sample. On the other hand, the dry ground sample showed a peak around As (V). This peak suggested that As was present as oxide. In addition, the sample after the elution test had a large oxide peak. The elution test for the sample after dry grinding improved oxidation. It was found that As was present as sulfide, and the mechanochemical effect of grinding caused a change in the chemical state of As from sulfide to oxide. Welham [22] reported that grinding of enargite caused the oxidation of As. The overall chemical reaction depending on oxygen consumption and atmospheric temperature is indicated as follows:

$$
4 \mathrm{Cu}_{3} \mathrm{AsS}_{4}+27 \mathrm{O}_{2} \rightarrow 12 \mathrm{CuSO}_{4}+4 \mathrm{~S}+2 \mathrm{As}_{2} \mathrm{O}_{3}
$$

The increased elution rate of the $\mathrm{As}$ and $\mathrm{Cu}$ of the ground samples may be due to the formation of $\mathrm{CuSO}_{4}$ and $\mathrm{As}_{2} \mathrm{O}_{3}$, both of which are soluble in water. In the meantime, of the oxidized minerals 
reported as alternates of enargite, scorodite $\mathrm{FeAsO}_{4} \cdot 2 \mathrm{H}_{2} \mathrm{O}$ is probably the most widespread [23]. The exact conditions of formation were never specified. However, given the very common coexistence of enargite and pyrite, the formation of scorodite from enargite can be depicted as a simple mechanism,

$$
\mathrm{Cu}_{3} \mathrm{AsS}_{4}+\mathrm{FeS}_{2}+12.5 \mathrm{O}_{2}+5 \mathrm{H}_{2} \mathrm{O} \rightarrow \mathrm{FeAsO}_{4} \cdot 2 \mathrm{H}_{2} \mathrm{O}+3 \mathrm{Cu}^{2+}+6 \mathrm{SO}_{4}{ }^{2-}+6 \mathrm{H}^{+} .
$$

Figure 2a,c demonstrates that As and Fe show the same elution behavior. Therefore, it is conceivable that As and Fe exist as the same compound within the same reaction.
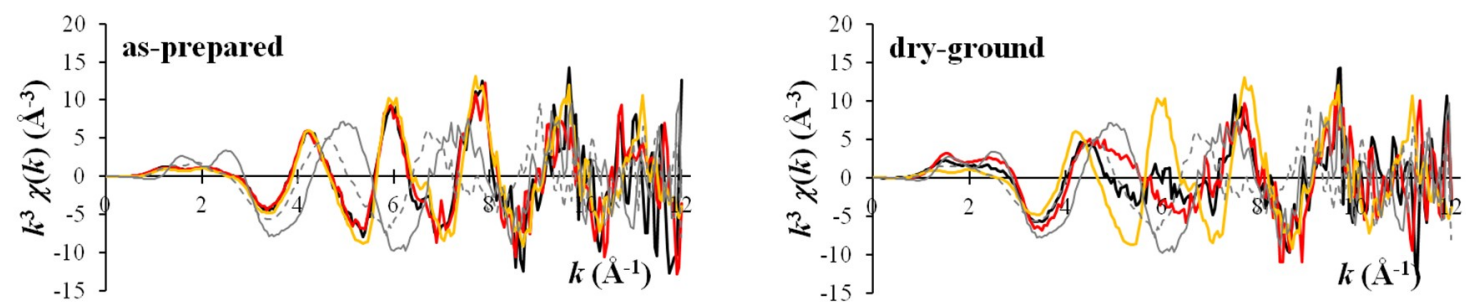

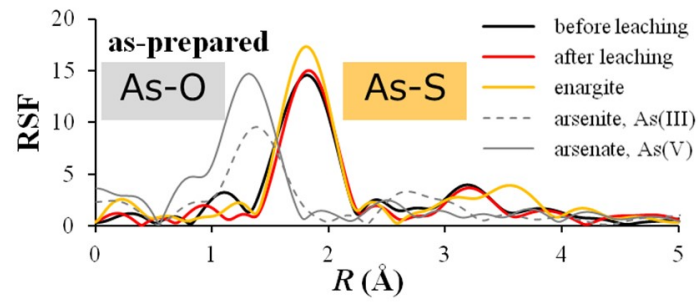

(a) Original

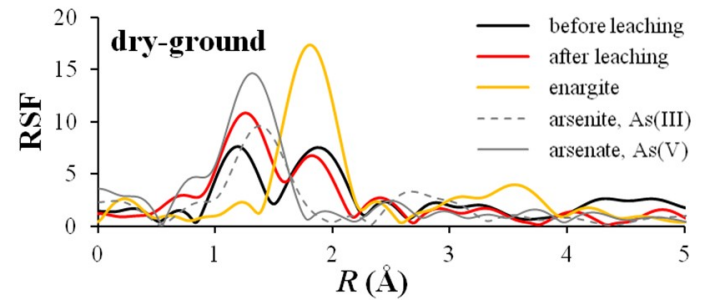

(b) Dry grinding

Figure 6. Radial structure functions obtained by Fourier transform of $k^{3}$ weighted extended X-ray absorption fine structure (EXAFS) spectra of the (a) original and (b) dry ground samples.

\subsection{Optimization of Mechanochemical Effect}

Mechanochemical treatment improves the oxidation of As, and as a result, As can be removed from copper ore by water washing. Here, the optimal grinding conditions were investigated, which improved the elution rate of As to water. Several preliminary tests indicated that combined dry and wet grinding is effective for the elution of As. Dry grinding mainly affects the amorphization of the sample and wet grinding mainly affects the reduction of the particle size. Combined grinding was carried out as follows. First, dry grinding was performed. The sample weight was $4 \mathrm{~g}$, the mass of balls was set to $75 \mathrm{~g}$, and the grinding time was $1 \mathrm{~h}$ to $8 \mathrm{~h}$. Second, $20 \mathrm{~mL}$ of distilled water were added to the pot after dry grinding and wet grinding was performed continuously using the same diameter of balls as in dry grinding. In wet grinding, the rotational speed was $600 \mathrm{rpm}$ and the grinding time was $5 \mathrm{~min}$. The conditions of wet grinding were fixed. Figure $5 \mathrm{~b}$ indicates that wet grinding achieved the grinding limit rapidly. The effects of the rotational speed of grinding are shown in Figure 7. The elution rate of As reached a maximum value at the rotational speed of $400 \mathrm{rpm}$, and the value was about $45 \%$. The elution rate of As increased with increasing rotational speed up to $400 \mathrm{rpm}$. Further increase of rotational speed caused a decrease in the elution rate of As. The elution rate of $\mathrm{Cu}$ became almost $0 \%$ above the rotational speed of $400 \mathrm{rpm}$, and it can be seen that the separation of As from copper ore succeeded. In the elution of As, it was found that an optimum rotational speed existed. Since rotational speed correlates with the intensity of grinding, there might be optimum ball diameter depending on rotational speed. The optimized grinding conditions are summarized in Table 2. The comparison of Case 1 to Case 2 shows the effect of rotational speed. The comparison of Case 1 to Cases 3 and 4 shows the effect of ball diameter. In order to further improve the elution rate of As, the $\mathrm{pH}$ of the solution was considered to affect the elution behavior of As. The effect of the concentration of sodium hydroxide aqueous and the type of solvent used was investigated (Case 5 to Case 11). Here, the $\mathrm{pH}$ of 
the solution after grinding was about 13 in all cases. The elution rate of As increased with increasing concentrations of sodium hydroxide aqueous, and the final elution rate showed a value of about $60 \%$. Other As solvents, potassium sulfide $\left(\mathrm{K}_{2} \mathrm{~S}\right)$, sodium carbonate $\left(\mathrm{Na}_{2} \mathrm{CO}_{3}\right)$, and sodium hydrogen carbonate $\left(\mathrm{NaHCO}_{3}\right)$, were used. In those cases, the elution rate of As was 32.5\%, 16.3\%, and 7.5\%, respectively, so the elution rate of As was highest when sodium hydroxide was used.

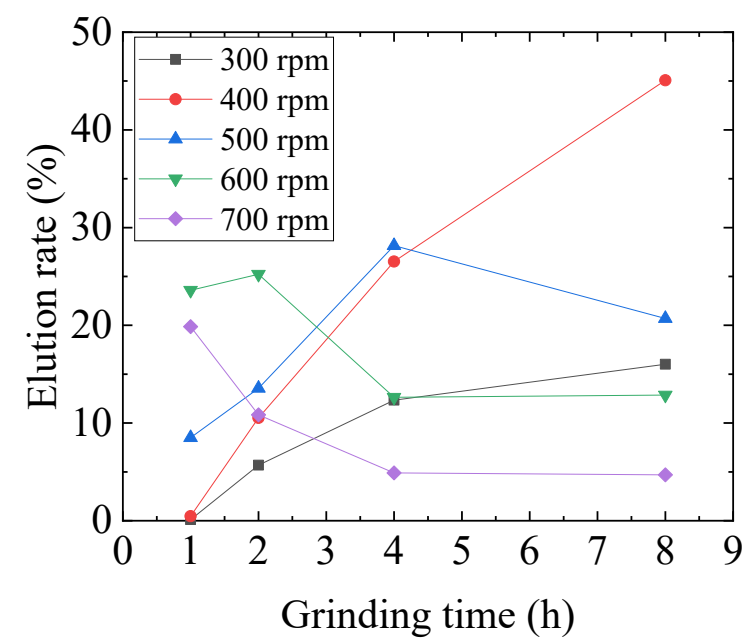

(a)

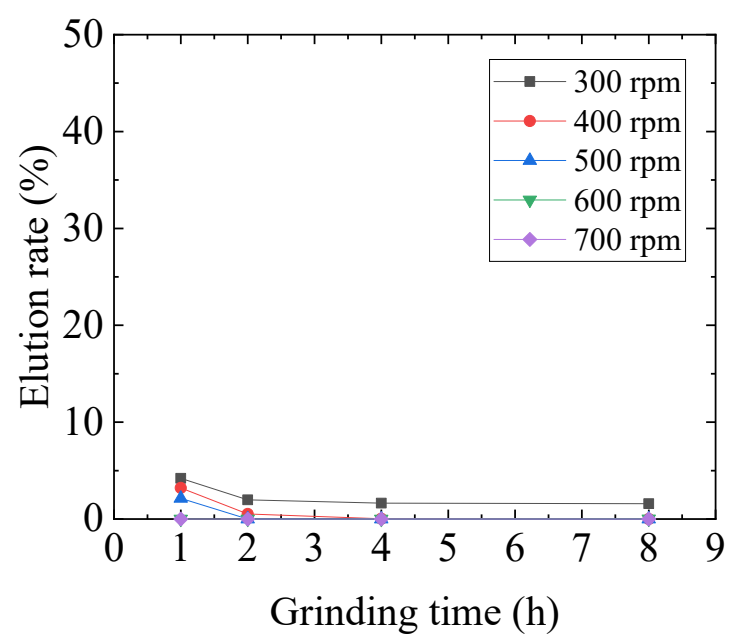

(b)

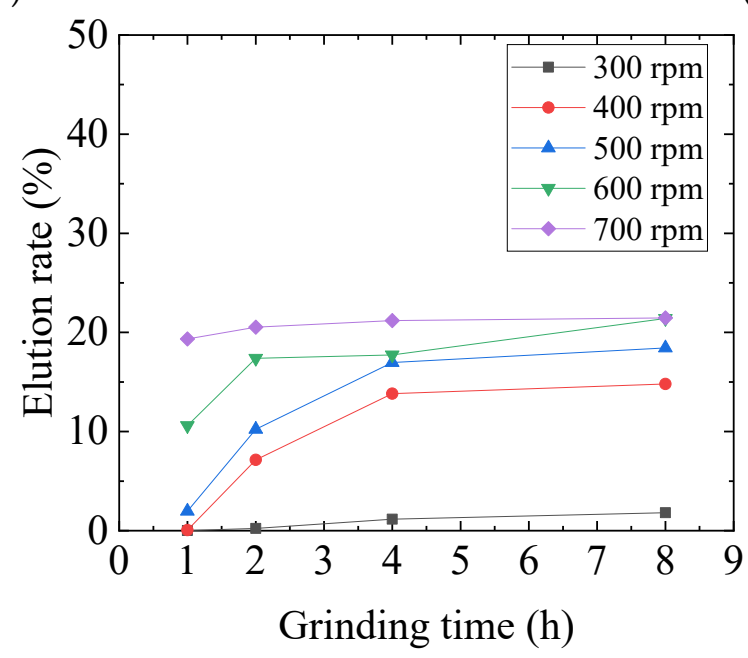

(c)

Figure 7. Elution rate of (a) As, (b) $\mathrm{Cu}$ and (c) Fe from combined ground samples at different rotational speeds.

In this study, various grinding conditions such as rotational speed, ball diameter, grinding time, and the type of solvent used affected the elution rate of As. The optimal conditions for the elution of As were searched for. As a result of trial and error, the elution rate of As finally showed a value of about $76 \%$ in Case 12. In this case, the grinding conditions were as follows. In dry grinding, the ball diameter was $10 \mathrm{~mm}$, the rotational speed was $400 \mathrm{rpm}$, and the grinding time was $8 \mathrm{~h}$. In continuous wet grinding, the type of solvent was sodium hydroxide. The ICP-MS analysis of the samples after grinding under these conditions is shown in Table 3 and compared with the components of the original ore (as shown in Table 1). The As concentration could be reduced to $1 / 4$ and the $\mathrm{Cu}$ concentration could be increased 1.5 times by combined grinding. 
Table 2. Summary of the optimization of grinding conditions. The elution rate of As, $\mathrm{Cu}$ and Fe from combined ground samples using different ball diameters, grinding times, rotational speeds, andtype and concentration of solvent.

\begin{tabular}{|c|c|c|c|c|c|c|c|}
\hline \multirow[b]{2}{*}{ Cases } & \multirow[b]{2}{*}{$\begin{array}{l}\text { Ball Diameter } \\
(\mathrm{mm})\end{array}$} & \multirow[b]{2}{*}{$\begin{array}{l}\text { Grinding } \\
\text { Time (h) }\end{array}$} & \multirow[b]{2}{*}{$\begin{array}{c}\text { Rotational } \\
\text { Speed (rpm) }\end{array}$} & \multirow{2}{*}{$\begin{array}{c}\text { Type of Solvent } \\
\text { Aqueous } \\
\text { Concentration (mol/L) }\end{array}$} & \multicolumn{3}{|c|}{ Elution rate $(\%)$} \\
\hline & & & & & As & $\mathrm{Cu}$ & $\mathrm{Fe}$ \\
\hline Case 1 & 15 & 8 & 600 & $\begin{array}{c}\text { Water } \\
-\end{array}$ & 12.86 & 0.00 & 21.4 \\
\hline Case 2 & 15 & 8 & 400 & $\begin{array}{c}\text { Water } \\
-\end{array}$ & 45.07 & 0.00 & 14.8 \\
\hline Case 3 & 10 & 8 & 600 & $\begin{array}{c}\text { Water } \\
-\end{array}$ & 48.18 & 0.00 & 15.96 \\
\hline Case 4 & 5 & 8 & 600 & $\begin{array}{c}\text { Water } \\
-\end{array}$ & 41.50 & 0.00 & 15.12 \\
\hline Case 5 & 15 & 1 & 600 & $\begin{array}{c}\mathrm{NaOH} \\
0.25\end{array}$ & 4.26 & 0.00 & 0.01 \\
\hline Case 6 & 15 & 1 & 600 & $\begin{array}{c}\mathrm{NaOH} \\
0.625\end{array}$ & 51.73 & 0.00 & 0.03 \\
\hline Case 7 & 15 & 1 & 600 & $\begin{array}{c}\mathrm{NaOH} \\
1.25\end{array}$ & 56.34 & 0.00 & 0.01 \\
\hline Case 8 & 15 & 1 & 600 & $\begin{array}{c}\mathrm{NaOH} \\
2.5\end{array}$ & 59.86 & 0.00 & 0.02 \\
\hline Case 9 & 15 & 1 & 600 & $\begin{array}{l}\mathrm{K}_{2} \mathrm{~S} \\
1.25\end{array}$ & 32.45 & 0.32 & 0.00 \\
\hline $\begin{array}{c}\text { Case } \\
10\end{array}$ & 15 & 1 & 600 & $\begin{array}{c}\mathrm{Na}_{2} \mathrm{CO}_{3} \\
1.25\end{array}$ & 16.31 & 0.00 & 1.71 \\
\hline Case 11 & 15 & 1 & 600 & $\begin{array}{c}\mathrm{NaHCO}_{3} \\
1.25\end{array}$ & 7.45 & 0.00 & 0.05 \\
\hline $\begin{array}{c}\text { Case } \\
12\end{array}$ & 10 & 8 & 400 & $\begin{array}{c}\mathrm{NaOH} \\
1.25\end{array}$ & 76.2 & 0.00 & 0.08 \\
\hline
\end{tabular}

Table 3. Chemical composition of copper ore concentrate used in this study, analyzed by ICP-MS.

\begin{tabular}{ccc}
\hline Principal Element & Combined Grinding (wt \%) & Original Ore (wt \%) \\
\hline $\mathrm{Cu}$ & 42.72 & 30.77 \\
$\mathrm{As}$ & 1.37 & 5.76 \\
$\mathrm{Fe}$ & 12.5 & 12.90 \\
$\mathrm{~S}$ & 21.5 & 28.80 \\
$\mathrm{Zn}$ & 1.24 & 2.06 \\
$\mathrm{~Pb}$ & 0.59 & 0.24 \\
\hline
\end{tabular}

\section{Conclusions}

This study found that grinding using a planetary ball mill as a mechanochemical treatment is useful for removing As from copper ore. The As was initially present as sulfide in copper ore, and it was converted to oxide by grinding and eluted into a water and alkaline solution. In order to clarify the chemical state of As, the compositions before and after grinding the samples were analyzed by XAS. The increased elution rate of the As and $\mathrm{Cu}$ of the ground samples may be due to the formation of $\mathrm{CuSO}_{4}$ and $\mathrm{As}_{2} \mathrm{O}_{3}$ both of which are soluble in water. The optimum grinding conditions for the elution rate of As, such as rotational speed, ball diameter, grinding time, and type of solvent were investigated. The elution rate of As finally showed a value of about $76 \%$. In this case, the grinding conditions were as follows. In dry grinding, the ball diameter was $10 \mathrm{~mm}$, the rotational speed was $400 \mathrm{rpm}$, and grinding time was $8 \mathrm{~h}$. In continuous wet grinding, the type of solvent was sodium hydroxide. The elution rate of As was affected by the elution time and the proportion of oxides increases after the elution of sulfide, meaning it might have changed into different sulfides. Alternatively, it is possible 
that the As oxidized by grinding dissolved first, and another oxide was produced during the elution test that was hard to dissolve in water. These elution phenomena progressed from the surface to the inside of the ore. It is necessary to measure the surface information after grinding and also after the elution test. To measure this information, conversion electrons yielded XAFS as effective. In this study, an in-house XAFS device was used, but such measurement requires the use of a more powerful synchrotron radiation facility. In future works, XAFS measurement by the conversion electron yield method will be performed and the progress of mechanochemical reactions will be clarified.

Author Contributions: S.I. performed the experiment and wrote the manuscript with the help of J.K.; K.S. performed the XAFS measurements and the data analysis.

Funding: This work was supported by JSPS KAKENHI, grant number 18K19041, and the Japan Oil, Gas and Metals National Corporation.

Conflicts of Interest: The authors declare no conflict of interest.

\section{References}

1. Leist, M.; Casey, R.J.; Caridi, D. The management of arsenic wastes: Problems and prospects. J. Hazard. Mater. 2000, 76, 125-138. [CrossRef]

2. Quintans-Fondo, A.; Fernandez-Calvino, D.; Novoa-Munoz, J.C.; Arias-Estevez, M.; Fernandez-Sanjurjo, M.J.; Alvarez-Rodriguez, E.; Nunez-Delgado, A. As(V) Sorption/Desorption on Different Waste Materials and Soil Samples. Int. J. Environ. Res. Public Health 2017, 14, 803. [CrossRef] [PubMed]

3. Gu, K.H.; Li, W.H.; Han, J.W.; Liu, W.; Qin, W.Q.; Cai, L.B. Arsenic removal from lead-zinc smelter ash by $\mathrm{NaOH}-\mathrm{H}_{2} \mathrm{O}_{2}$ leaching. Sep. Purif. Technol. 2019, 209, 128-135. [CrossRef]

4. Rathore, V.K.; Mondal, P. Stabilization of arsenic and fluoride bearing spent adsorbent in clay bricks: Preparation, characterization and leaching studies. J. Environ. Manag. 2017, 200, 160-169. [CrossRef] [PubMed]

5. Dosmukhamedov, N.; Kaplan, V. Efficient Removal of Arsenic and Antimony during Blast Furnace Smelting of Lead-Containing Materials. JOM 2017, 69, 381-387. [CrossRef]

6. Huang, J.-H.; Tian, L.; Ilgen, G. Biogenic arsenic volatilisation from an acidic fen. Sci. Total Environ. 2018, 615, 1470-1477. [CrossRef] [PubMed]

7. Liu, H.; Wang, C.; Zou, C.; Zhang, Y.; Wang, J. Simultaneous volatilization characteristics of arsenic and sulfur during isothermal coal combustion. Fuel 2017, 203, 152-161. [CrossRef]

8. Morales, A.; Cruells, M.; Roca, A.; Bergo, R. Treatment of copper flash smelter flue dusts for copper and zinc extraction and arsenic stabilization. Hydrometallurgy 2010, 105, 148-154. [CrossRef]

9. Han, J.; Liu, W.; Qin, W.; Zhang, T.; Chang, Z.; Xue, K. Effects of sodium salts on the sulfidation of lead smelting slag. Min. Eng. 2017, 108, 1-11. [CrossRef]

10. Kashiwakura, S.; Ohno, H.; Matsubae-Yokoyarna, K.; Kumagai, Y.; Kubo, H.; Nagasaka, T. Removal of arsenic in coal fly ash by acid washing process using dilute $\mathrm{H}_{2} \mathrm{SO}_{4}$ solvent. J. Hazard. Mater. 2010, 181, 419-425. [CrossRef]

11. Liu, R.; Yang, Z.; He, Z.; Wu, L.; Hu, C.; Wu, W.; Qu, J. Treatment of strongly acidic wastewater with high arsenic concentrations by ferrous sulfide (FeS): Inhibitive effects of S(0)-enriched surfaces. Chem. Eng. J. 2016, 304, 986-992. [CrossRef]

12. Awe, S.A.; Sandstrom, A. Selective leaching of arsenic and antimony from a tetrahedrite rich complex sulphide concentrate using alkaline sulphide solution. Min. Eng. 2010, 23, 1227-1236. [CrossRef]

13. Tongamp, W.; Takasaki, Y.; Shibayama, A. Arsenic removal from copper ores and concentrates through alkaline leaching in NaHS media. Hydrometallurgy 2009, 98, 213-218. [CrossRef]

14. Lewis, A.E. Review of metal sulphide precipitation. Hydrometallurgy 2010, 104, 222-234. [CrossRef]

15. Granata, G.; Takahashi, K.; Kato, T.; Tokoro, C. Mechanochemical activation of chalcopyrite: Relationship between activation mechanism and leaching enhancement. Min. Eng. 2019, 131, 280-285. [CrossRef]

16. Kato, T.; Granata, G.; Tsunazawa, Y.; Takagi, T.; Tokoro, C. Mechanism and kinetics of enhancement of cerium dissolution from weathered residual rare earth ore by planetary ball milling. Min. Eng. 2019, 134, 365-371. [CrossRef] 
17. Mohammadabad, F.K.; Hejazi, S.; Khaki, J.V.; Babakhani, A. Mechanochemical leaching of chalcopyrite concentrate by sulfuric acid. Int. J. Min. Metall. Mater. 2016, 23, 380-388. [CrossRef]

18. Achimovicova, M.; Balaz, P.; Briancin, J. The influence of mechanical activation of chalcopyrite on the selective leaching of copper by sulphuric acid. Metalurgija 2006, 45, 9-12.

19. Taguchi, T.; Harada, J.; Kiku, A.; Tohji, K.; Shinoda, K. Development of a new in-laboratory XAFS apparatus based on new concept. J. Synchrotron Radiat. 2001, 8, 363-365. [CrossRef]

20. Ankudinov, A.L.; Ravel, B.; Rehr, J.J.; Conradson, S.D. Real-space multiple-scattering calculation and interpretation of x-ray-absorption near-edge structure. Phys. Rev. B 1998, 58, 7565-7576. [CrossRef]

21. Ankudinov, A.L.; Bouldin, C.E.; Rehr, J.J.; Sims, J.; Hung, H. Parallel calculation of electron multiple scattering using Lanczos algorithms. Phys. Rev. B 2002, 65, 104107. [CrossRef]

22. Welham, N.J. Mechanochemical processing of enargite $\left(\mathrm{Cu}_{3} \mathrm{AsS}_{4}\right)$. Hydrometallurgy 2001, 62, $165-173$. [CrossRef]

23. Lattanzi, P.; Da Pelo, S.; Musu, E.; Atzei, D.; Elsener, B.; Fantauzzi, M.; Rossi, A. Enargite oxidation: A review. Earth Sci. Rev. 2008, 86, 62-88. [CrossRef]

(C) 2019 by the authors. Licensee MDPI, Basel, Switzerland. This article is an open access article distributed under the terms and conditions of the Creative Commons Attribution (CC BY) license (http://creativecommons.org/licenses/by/4.0/). 